\title{
Studi Perencanaan Sumur Injeksi Dalam Upaya Penanggulangan Genangan Di Kawasan Perkotaan (Studi Kasus Di RW. 8 Dan 9 - Kelurahan Blimbing, Kota Malang)
}

\author{
Annisa Zuyyinani'ma Syafira ${ }^{1 *}$, Mohammad Bisri ${ }^{1}$, Runi \\ Asmaranto ${ }^{1}$ \\ ${ }^{1}$ Jurusan Teknik Pengairan, Fakultas Teknik, Universitas Brawijaya \\ J1. MT. Haryono No. 167, Malang, 65145, Indonesia
}

*Korespondensi Email : annisasyafira045@gmail.com

\begin{abstract}
RW.8 and 9 areas, Blimbing Sub-district, Malang city is one of the areas that often occur inundation due to changes in land cover and narrowing of drainage channels. The solution is the manufacture of injection wells to determine the inundation, planning, and effectiveness of injection wells at the research site. To analyze it, modeling rain inundation a return period of 2 years and 5 years using Storm Water Management Model (SWMM) 5.1 application. Calibration results showed for the Root Mean Square Error (RMSE) value, modeling discharge and measurable discharge for a return period of 2 years is $17.3 \%$, and a return period of 5 years is $20.9 \%$. The simulation results showed the capacity of existing drainage channels for a return period of 2 years and 5 years resulted in 8 channels overflowing from 42 existing channels with the number of injection wells needed as many as 45 injection wells for 8 water catchment areas. The effectiveness value of the application of injection wells using rain barrels obtained results for a return period of 2 years is $66.67 \%-93.33 \%$ with average injection well effectiveness is $84.66 \%$ and a return period of 5 years is $66 \%-95 \%$ with average injection well effectiveness is $84.78 \%$.
\end{abstract}

Keywords: Calibration, Injection Wells, Modeling, Rain Barrel, SWMM 5.1

Abstrak: Wilayah RW.8 dan 9, Kelurahan Blimbing, Kecamatan Blimbing, Kota Malang merupakan salah satu contoh daerah yang sering terjadinya genangan akibat perubahan penutup lahan serta penyempitan saluran drainase. Contoh penanganannya yaitu dengan pembuatan sumur injeksi yang bertujuan untuk mengetahui genangan, perencanaan dan efektivitas sumur injeksi di lokasi penelitian. Untuk menganalisanya, pemodelan genangan hujan kala ulang 2 tahun dan 5 tahun menggunakan aplikasi Storm Water Management Model (SWMM) 5.1. Hasil kalibrasi menunjukkan nilai Root Mean Square Error (RMSE) debit pemodelan 
dengan debit terukur untuk kala ulang 2 tahun sebesar 17,3\% dan kala ulang 5 tahun sebesar 20,9\%. Hasil simulasi menunjukkan kapasitas saluran drainase eksisting kala ulang 2 tahun dan 5 tahun mengakibatkan terdapat 8 saluran yang meluap dari 42 saluran yang ada dengan jumlah sumur injeksi yang dibutuhkan sebanyak 45 sumur injeksi untuk 8 daerah tangkapan air. Nilai efektivitas penerapan sumur injeksi dengan menggunakan rain barrel didapatkan hasil untuk kala ulang 2 tahun sebesar 66,67\%-93,33\% dengan rata-rata efektivitas sumur injeksi sebesar $84,66 \%$ dan kala ulang 5 tahun sebesar 66\%-95\% dengan rata-rata efektivitas sumur injeksi sebesar 84,78\%.

Kata kunci: Kalibrasi, Pemodelan, Rain Barrel, Sumur Injeksi, SWMM 5.1

\section{Pendahuluan}

Kota Malang merupakan salah satu contoh daerah perkotaan yang setiap tahunnya terjadi peningkatan pertumbuhan penduduk serta pembangunan yang berdampak terhadap perubahan alih fungsi lahan misalnya pada kawasan permukiman. Perubahan penggunaan lahan akibat pembangunan perumahan, secara tidak langsung dapat merusak kawasan resapan air[1]. Hal ini yang menyebabkan semakin berkurangnya daerah resapan air hujan yang menyebabkan terjadinya penumpukan air hujan pada saluran drainase [1].

Kondisi tersebut akibat luapan air hujan di dalam saluran yang dapat menimbulkan terjadinya genangan atau bahkan banjir. Salah satu contoh kasus permukiman yang memiliki genangan yang cukup besar berada di wilayah RW. 8 dan 9 Kelurahan Blimbing, Kecamatan Blimbing, Kota Malang sebagai akibat perubahan penutup lahan.

Sumur injeksi adalah sarana yang berfungsi untuk menampung air hujan dan meresapkan air ke dalam tanah. Air hujan yang jatuh dari atap tidak langsung dialirkan ke selokan atau halaman rumah, tetapi terlebih dahulu dialirkan melalui pipa atau saluran air ke dalam sumur injeksi sehingga dapat mengurangi genangan yang terjadi[1]. Agar dapat mengetahui besarnya genangan yang terjadi pada daerah tersebut diperlukan analisis menggunakan model aplikasi EPA SWMM 5.1 Storm Water Management Model (SWMM) 5.1. merupakan model yang mampu untuk menganalisa permasalahan kuantitas dan kualitas air yang berkaitan dengan genangan di daerah perkotaan [2].

Oleh sebab itu, diperlukan adanya penelitian di kawasan RW.8 dan 9 Kelurahan Blimbing, Kecamatan Blimbing, Kota Malang yang berdasarkan observasi langsung dengan melihat kondisi saluran drainase yang ada serta terjadinya genangan atau banjir yang terjadi di wilayah tersebut ketika musim hujan. Penelitian ini direncanakan untuk mengetahui genangan yang terjadi dan perencanaan sumur injeksi yang diperlukan dalam mereduksi genangan permukaan. Selanjutnya dibandingkan persentase penggunaan sumur injeksi untuk mengetahui jumlah sumur injeksi yang dapat mengurangi genangan permukaan di RW.8 dan 9 Kelurahan Blimbing, Kecamatan Blimbing, Kota Malang dengan menggunakan model aplikasi EPA SWMM 5.1. 


\section{Bahan dan Metode}

\subsection{Bahan}

\subsubsection{Daerah Studi}

Daerah studi atau lokasi penelitian berada di Kelurahan Blimbing RW 8 dan 9, Kecamatan Blimbing, Kota Malang. Kelurahan Blimbing memiliki luas wilayah sekitar 109,5 ha. Suhu maksimum di Kelurahan Blimbing berkisar 24 hingga 36 derajat Celsius. Kelurahan ini terdiri dari 10 RW (Rukun Warga) dan 55 RT (Rukun Tetangga). Kelurahan ini dihuni oleh 10.617 jiwa yang terbagi menjadi 2.086 KK (Kepala Keluarga). Jumlah tersebut terdiri dari 5.298 orang pria dan 5.319 orang wanita. Di bawah ini merupakan Peta Kejadian Cuaca Ekstrim Kecamatan Blimbing Kota Malang Tahun 2015-2017 menurut dari Badan Penanggulangan Bencana Daerah Kota Malang yang dapat dilihat pada Gambar 1 sebagai berikut.

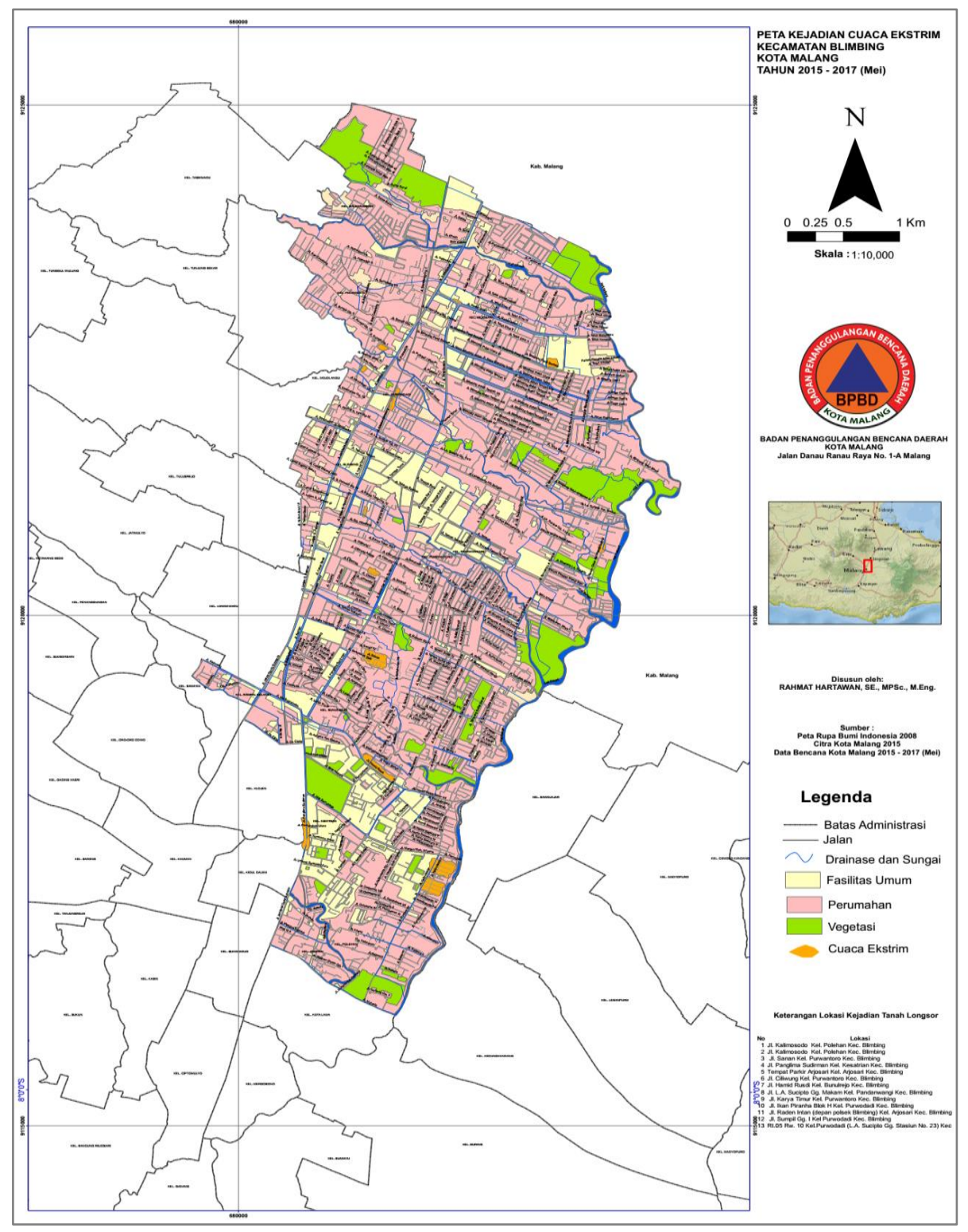

Gambar 1: Peta Kejadian Cuaca Ekstrim Kelurahan Blimbing 


\subsubsection{Data Penelitian}

Dalam studi penelitian ini dibutuhkan data untuk menunjang studi kali ini, dan berikut data yang dibutuhkan:

a. Data Primer

- Koordinat saluran

- Dimensi saluran (panjang dan kedalaman saluran)

b. Data Sekunder

- Data hujan Stasiun Blimbing (2010-2019)

- Peta jaringan drainase

\subsection{Metode}

Untuk metode penelitian ini melakukan perhitungan analisa hidrologi yaitu: Uji Konsistensi Data (Metode RAPS), Analisa Frekuensi (Distribusi Gumbel dan Log Pearson III), Uji Kecocokan Data (Smirnov-Kolmogorov dan Chi Square III), dan Perhitungan Intensitas Hujan. Hasil akhirnya adalah intensitas curah hujan dengan kala ulang tertentu yang digunakan sebagai input rain gage pada software EPA SWMM [3]. Melakukan pemodelan pada aplikasi SWMM 5.1. Pemodelan SWMM dilakukan setelah semua data terkumpul, yaitu rain gage, subcatchment, conduit, junction, dan outfalls untuk kala ulang 2 dan 5 tahun[4]. Setelah input data-data pada SWMM 5.1 telah terkumpul, dilakukan running simulation pada SWMM 5.1 [5]. Didapatkan hasil saluran yang mengalami genangan pada lokasi penelitian. Setelah melakukan pembandingan kapasitas eksisiting dengan debit rancangan dilanjutkan dengan penggunaan alternatif penanggulangan genangan yaitu perencanaan sumur injeksi. Parameter sumur injeksi dimasukkan ke dalam aplikasi SWMM 5.1, didapatkan hasil nilai efektivitas sumur injeksi untuk mereduksi genangan yang terjadi di daerah tersebut.

\section{Hasil dan Pembahasan}

\subsection{Analisa Konsistensi Data Hujan}

Uji konsistensi data hujan menggunakan metode Rescaled Adjusted Partial Sums (RAPS) atau uji kepanggahan [6]. Cara ini dilakukan dengan cara menghitung nilai kumulatif penyimpangannya terhadap nilai rata-rata (mean). Bila $\mathrm{Q} / \mathrm{n}$ yang didapat lebih kecil dari nilai kritik untuk tahun dan confidence level yang sesuai, maka data dinyatakan panggah [6]. Uji RAPS dilakukan hingga batas konsistensi 90\% - 99\%. Hasil dari nilai konsistensi 90\%-99\% dapat dilihat pada Tabel 1 di bawah ini sebagai berikut.

Tabel 1: Hasil Uji Konsistensi 90\%-99\%

\begin{tabular}{|l|l|l|l|l|l|}
\hline $\mathrm{Q} / \mathrm{n}^{0.5}=$ & 0.75 & $<$ & 1.05 & $===>$ & Memenuhi Syarat \\
\hline $\mathrm{R} / \mathrm{n}^{0.5}=$ & 1.21 & $<$ & 1.21 & $===>$ & Memenuhi Syarat \\
\hline $\mathrm{Q} / \mathrm{n}^{0.5}=$ & 0.75 & $<$ & 1.14 & $===>$ & Memenuhi Syarat \\
\hline $\mathrm{R} / \mathrm{n}^{0.5}=$ & 1.21 & $<$ & 1.28 & $==>$ & Memenuhi Syarat \\
\hline $\mathrm{Q} / \mathrm{n}^{0.5}=$ & 0.75 & $<$ & 1.29 & $===>$ & Memenuhi Syarat \\
\hline $\mathrm{R} / \mathrm{n}^{0.5}=$ & 1.21 & $<$ & 1.38 & $===>$ & Memenuhi Syarat \\
\hline
\end{tabular}




\subsection{Analisa Intensitas Hujan}

Dengan asumsi bahwa rata-rata hujan di Indonesia berdurasi selama 6 jam, maka perhitungan distribusi curah hujan jam-jaman selengkapnya dapat dilihat pada Tabel 2. Untuk daerah di Indonesia rata-rata $\mathrm{t}=6$ jam, maka :

$$
\begin{array}{lll}
\mathrm{T} & =1 \mathrm{jam}, \mathrm{R} 1=\mathrm{R}_{24} / 6 \times(6 / 1)^{2 / 3}=0.5503 \times \mathrm{R}_{24} & \text { Pers. } 1 \\
\mathrm{~T}=2 \mathrm{jam}, \mathrm{R} 2=\mathrm{R}_{24} / 6 \times(6 / 2)^{2 / 3}=0.3467 \times \mathrm{R}_{24} & \text { Pers. 2 } \\
\mathrm{T}=3 \mathrm{jam}, \mathrm{R} 3=\mathrm{R}_{24} / 6 \times(6 / 3)^{2 / 3}=0.2646 \times \mathrm{R}_{24} & \text { Pers. 3 } \\
\mathrm{T}=4 \mathrm{jam}, \mathrm{R} 4=\mathrm{R}_{24} / 6 \times(6 / 4)^{2 / 3}=0.2184 \times \mathrm{R}_{24} & \text { Pers. 4 } \\
\mathrm{T}=5 \mathrm{jam}, \mathrm{R} 5=\mathrm{R}_{24} / 6 \times(6 / 5)^{2 / 3}=0.1882 \times \mathrm{R}_{24} & \text { Pers. 5 } \\
\mathrm{T}=6 \text { jam, R6 }=\mathrm{R}_{24} / 6 \times(6 / 6)^{2 / 3}=0.1667 \times \mathrm{R}_{24} & \text { Pers. 6 }
\end{array}
$$

\begin{tabular}{|c|c|c|c|c|c|c|c|}
\hline \multirow{2}{*}{ No } & \multirow{2}{*}{ Jam Ke } & \multirow{2}{*}{ Nisbah (\%) } & \multicolumn{5}{|c|}{ Hujan Jam-Jaman (mm/hari) } \\
\hline & & & 2 th & 5 th & 10th & 20th & 25 th \\
\hline 1 & 1,00 & 55,03 & 44,51 & 56,00 & 64,24 & 71,06 & 74,72 \\
\hline 2 & 2,00 & 14,30 & 11,57 & 14,56 & 16,70 & 18,47 & 19,42 \\
\hline 3 & 3,00 & 10,03 & 8,12 & 10,21 & 11,71 & 12,96 & 13,62 \\
\hline 4 & 4,00 & 7,99 & 6,46 & 8,13 & 9,33 & 10,31 & 10,85 \\
\hline 5 & 5,00 & 6,75 & 5,46 & 6,86 & 7,87 & 8,71 & 9,16 \\
\hline 6 & 6,00 & 5,90 & 4,77 & 6,00 & 6,88 & 7,61 & 8,01 \\
\hline \multicolumn{3}{|c|}{ Probabilitas Hujan harian $(\mathrm{mm})$} & 107,85 & 135,69 & 155,65 & 172,16 & 181,04 \\
\hline \multicolumn{3}{|c|}{ Koefisien pengaliran } & 0,75 & 0,75 & 0,75 & 0,75 & 0,75 \\
\hline \multicolumn{3}{|c|}{ Huian Efektif (mm/hari) } & 80.89 & 101,76 & 11674 & 129,12 & 135.78 \\
\hline
\end{tabular}

Sementara itu, rumus untuk curah hujan jam-jaman ke $\mathrm{T}$, yaitu :

$$
\text { Rumus Rt }=(\mathrm{t} \times \mathrm{Rt})-((\mathrm{t}-1)(\mathrm{Rt}-1))
$$

Pers.7

dengan $\mathrm{Rt}=$ persentase intensitas

Tabel 2: Perhitungan Distribusi Curah Hujan

Contoh perhitungan intensitas hujan untuk jam ke-1 kala ulang 2 tahun :

$$
\begin{array}{ll}
\text { Hujan rancangan } & =107,851 \mathrm{~mm} \\
\text { Koefisien pengaliran } & =0,75[7] \\
\text { Rasio } & =55,03 \% \\
\text { Curah hujan efektif } & =\mathrm{k} \times \mathrm{R}_{2 \text { Tahun }}=0,75 \times 107,851 \mathrm{~mm}=80,89 \mathrm{~mm} / \text { hari } \\
\text { Hujan jam ke-1 } & =\text { Hujan efektif } \times \text { Rasio } / 100 \\
& =(80,89 \mathrm{~mm} / \text { hari } \times 55,03) / 100)=44,51 \mathrm{~mm} / \text { hari }
\end{array}
$$

Dari hasil perhitungan intensitas hujan jam-jaman dibuat grafik intensitas hujan jamjaman dengan kala ulang 2 dan 5 tahun yang dapat dilihat pada Gambar 2 sebagai berikut.

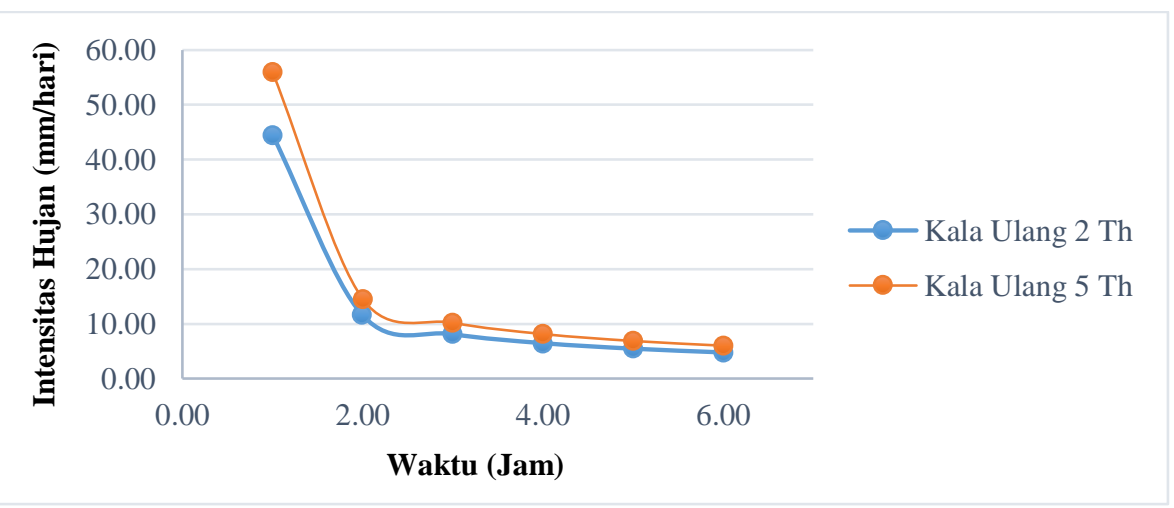

Gambar 2: Lengkung Intensitas Hujan dengan Kala Ulang 2 dan 5 Tahun 


\subsection{Kalibrasi Pemodelan}

Kalibrasi adalah sebuah cara untuk proses verifikasi untuk menentukan dan menyesuaikan kebenaran dari hasil simulasi Software Storm Water Management Model (SWMM 5.1) dengan kondisi sebenarnya yang ada di lapangan. Salah satu uji statistik yang digunakan untuk kalibrasi, validasi dan verifikasi model adalah Root Mean Square Errors (RMSE)[8]. Nilai RMSE mensyaratkan mendekati nol (0) [8].

Kalibrasi model dilakukan dengan cara membandingkan debit pada saluran yang ada di lapangan dengan debit hasil simulasi dari aplikasi SWMM 5.1[9]. Debit air yang digunakan sebagai data pembanding kalibrasi adalah data debit saluran di lokasi/titik observasi sampel saat terjadinya hujan tanggal 5 Desember 2020. Kemudian untuk saluran pada model simulasi disesuaikan dengan titik observasi menggunakan saluran 5. Rekapitulasi kalibrasi pemodelan untuk kala ulang 2 tahun dan 5 tahun pada aplikasi Storm Water Management Model (SWMM 5.1) disajikan dalam Tabel 3 dan Tabel 4.

Tabel 3: Perhitungan Kalibrasi Pemodelan Metode RMSE untuk Kala Ulang 2 Tahun

\begin{tabular}{|c|c|c|c|c|c|c|c|c|c|}
\hline \multirow{3}{*}{$\begin{array}{c}\text { Saluran } \\
\text { Observasi }\end{array}$} & \multirow{2}{*}{\multicolumn{5}{|c|}{ Observasi }} & \multirow{2}{*}{\multicolumn{2}{|c|}{$\begin{array}{c}\mathrm{Q}\left(\mathrm{m}^{3} / \mathrm{dt}\right) \\
\text { Saluran } \mathrm{C} 11 \\
\end{array}$}} & \multirow{3}{*}{$\begin{array}{l}\text { (Qobs - } \\
\text { Qsim) }^{2}\end{array}$} & \multirow{3}{*}{ RMSE } \\
\hline & & & & & & & & & \\
\hline & $\begin{array}{c}\text { Durasi } \\
\text { (menit) }\end{array}$ & $\begin{array}{l}\mathrm{h} \text { air } \\
\text { (m) }\end{array}$ & $\begin{array}{c}\mathrm{V} \\
(\mathrm{m} / \mathrm{dt})\end{array}$ & $\begin{array}{c}\text { A } \\
\left(\mathrm{m}^{2}\right)\end{array}$ & $\begin{array}{c}\mathrm{Q} \\
\left(\mathrm{m}^{3} / \mathrm{dt}\right)\end{array}$ & Simulasi & Observasi & & \\
\hline \multirow{11}{*}{$\begin{array}{c}\text { Saluran C5 } \\
\text { dengan } \\
\text { lebar } 1,1 \mathrm{~m}\end{array}$} & 15 & 0,02 & 0,1 & 0,022 & 0,0022 & 0 & 0,0022 & 0,000005 & \multirow{10}{*}{0,1731154} \\
\hline & 30 & 0,06 & 0,3 & 0,066 & 0,0198 & 0 & 0,0198 & 0,000392 & \\
\hline & 45 & 0,06 & 0,3 & 0,066 & 0,0198 & 0 & 0,0198 & 0,000392 & \\
\hline & 60 & 0,03 & 0,25 & 0,033 & 0,0083 & 0 & 0,0083 & 0,000068 & \\
\hline & 75 & 0,03 & 0,25 & 0,033 & 0,0083 & 0,21 & 0,0083 & 0,040703 & \\
\hline & 90 & 0,03 & 0,25 & 0,033 & 0,0083 & 0,26 & 0,0083 & 0,063378 & \\
\hline & 105 & 0,02 & 0,2 & 0,022 & 0,0044 & 0,28 & 0,0044 & 0,075955 & \\
\hline & 120 & 0,03 & 0,2 & 0,033 & 0,0066 & 0,29 & 0,0066 & 0,080316 & \\
\hline & 135 & 0,03 & 0,25 & 0,033 & 0,0083 & 0,15 & 0,0083 & 0,020093 & \\
\hline & 150 & 0,02 & 0,2 & 0,022 & 0,0044 & 0,14 & 0,0044 & 0,018387 & \\
\hline & & & & & & \multicolumn{2}{|r|}{$\sum=$} & 0,29968945 & $\mathrm{n}=10$ \\
\hline
\end{tabular}

RMSE $=\sqrt{\frac{1}{n} x \sum_{i=1}^{n} 0,29968945}=\sqrt{\frac{1}{10} x \sum_{i=1}^{n} 0,29968945}=0,1731154 \rightarrow \mathbf{0 , 1 7 3}$ (nilai mendekati 0 , maka kalibrasi sudah baik dan mendekati kondisi sebenarnya)

Tabel 4: Perhitungan Kalibrasi Pemodelan Metode RMSE untuk Kala Ulang 5 Tahun

\begin{tabular}{|c|c|c|c|c|c|c|c|c|c|}
\hline \multirow{2}{*}{$\begin{array}{c}\text { Saluran } \\
\text { Observasi }\end{array}$} & \multicolumn{5}{|c|}{ Observasi } & \multicolumn{2}{|c|}{$\begin{array}{c}\mathrm{Q}\left(\mathrm{m}^{3} / \mathrm{dt}\right) \\
\text { Saluran } \mathrm{C} 11\end{array}$} & \multirow{2}{*}{$(\text { Qobs - Qsim) })^{2}$} & \multirow{2}{*}{ RMSE } \\
\hline & $\begin{array}{l}\text { Durasi } \\
\text { (menit) }\end{array}$ & $\begin{array}{c}\text { h air } \\
(\mathrm{m})\end{array}$ & $\begin{array}{c}\mathrm{V} \\
(\mathrm{m} / \mathrm{dt})\end{array}$ & $\begin{array}{c}\mathrm{A} \\
\left(\mathrm{m}^{2}\right)\end{array}$ & $\begin{array}{c}\mathrm{Q} \\
\left(\mathrm{m}^{3} / \mathrm{dt}\right)\end{array}$ & Simulasi & Observasi & & \\
\hline \multirow{11}{*}{$\begin{array}{c}\text { Saluran C5 } \\
\text { dengan } \\
\text { lebar } 1,1 \mathrm{~m}\end{array}$} & 15 & 0,02 & 0,1 & 0,022 & 0,0022 & 0 & 0,0022 & 0,000005 & \multirow{10}{*}{0,209364} \\
\hline & 30 & 0,06 & 0,3 & 0,066 & 0,0198 & 0 & 0,0198 & 0,000392 & \\
\hline & 45 & 0,06 & 0,3 & 0,066 & 0,0198 & 0 & 0,0198 & 0,000392 & \\
\hline & 60 & 0,03 & 0,25 & 0,033 & 0,0083 & 0 & 0,0083 & 0,000068 & \\
\hline & 75 & 0,03 & 0,25 & 0,033 & 0,0083 & 0,27 & 0,0083 & 0,068513 & \\
\hline & 90 & 0,03 & 0,25 & 0,033 & 0,0083 & 0,31 & 0,0083 & 0,091053 & \\
\hline & 105 & 0,02 & 0,2 & 0,022 & 0,0044 & 0,34 & 0,0044 & 0,112627 & \\
\hline & 120 & 0,03 & 0,2 & 0,033 & 0,0066 & 0,35 & 0,0066 & 0,117924 & \\
\hline & 135 & 0,03 & 0,25 & 0,033 & 0,0083 & 0,17 & 0,0083 & 0,026163 & \\
\hline & 150 & 0,02 & 0,2 & 0,022 & 0,0044 & 0,15 & 0,0044 & 0,021199 & \\
\hline & & & & & & & $\sum=$ & 0,43833645 & $\mathrm{n}=10$ \\
\hline
\end{tabular}


RMSE $=\sqrt{\frac{1}{n} x \sum_{i=1}^{n} 0,43833645}=\sqrt{\frac{1}{10} x \sum_{i=1}^{n} 0,43833645}=0,2093649 \rightarrow \mathbf{0 , 2 0 9}$ (nilai mendekati 0 , maka kalibrasi sudah baik dan mendekati kondisi sebenarnya)

\subsection{Simulasi Kondisi Drainase Eksisting}

\subsubsection{Kala Ulang 2 Tahun}

Dalam melakukan pemodelan saluran drainase di wilayah RW.8 dan 9, Kelurahan Blimbing dengan menggunakan program EPA-SWMM diperoleh beberapa hasil. Genangan permukaan (surface runoff) merupakan salah satu hasil yang didapatkan pada aplikasi SWMM 5.1 yang akan dikaji pada studi penelitian ini [9]. Hasil dari simulasi debit genangan per saluran kondisi eksisting yang mengalami luapan kala ulang 2 tahun dapat dilihat pada Tabel 5 sebagai berikut.

Tabel 5: Hasil Simulasi Debit Genangan per Saluran Kondisi Eksisting

\begin{tabular}{ccccccccc}
\hline No & $\begin{array}{c}\text { Nama } \\
\text { Saluran }\end{array}$ & $\begin{array}{c}\text { Lebar } \\
\text { Saluran } \\
(\mathrm{m})\end{array}$ & $\begin{array}{c}\text { Tinggi } \\
\text { Saluran } \\
(\mathrm{m})\end{array}$ & $\begin{array}{c}\text { Diameter } \\
(\mathrm{m})\end{array}$ & $\begin{array}{c}\text { Tinggi Air } \\
\text { Maksimum } \\
\text { di Saluran }(\mathrm{m})\end{array}$ & $\begin{array}{c}\text { Kecepatan } \\
\text { Maksimum } \\
(\mathrm{m} / \mathrm{dtk})\end{array}$ & $\begin{array}{c}\text { Debit } \\
\text { Maksimum } \\
\left(\mathrm{m}^{3} / \mathrm{dtk}\right)\end{array}$ & Ket. \\
\hline 1 & $\mathrm{C} 2$ & - & - & 0,16 & 0,16 & 0,77 & 0,014 & Meluap \\
2 & C9 & - & - & 0,1 & 0,10 & 0,33 & 0,002 & Meluap \\
3 & C19 & 0,3 & 0,15 & - & 0,15 & 1,23 & 0,055 & Meluap \\
4 & C33 & - & - & 0,16 & 0,16 & 0,61 & 0,012 & Meluap \\
5 & C38 & 0,2 & 0,3 & - & 0,30 & 0,79 & 0,046 & Meluap \\
6 & C39 & 0,3 & 0,2 & - & 0,20 & 1,60 & 0,093 & Meluap \\
7 & C40 & 0,25 & 0,2 & - & 0,20 & 0,60 & 0,025 & Meluap \\
8 & C42 & - & - & 0,16 & 0,16 & 0,55 & 0,010 & Meluap \\
\hline
\end{tabular}

Pada tabel 5 didapatkan hasil terdapat 8 saluran yang meluap. Hal ini dikarenakan tinggi saluran dan tinggi air maksimum di saluran sama yang mengakibatkan saluran tidak mampu menampung genangan.

\subsubsection{Kala Ulang 5 Tahun}

Sedangkan, hasil dari simulasi debit genangan per saluran kondisi eksisting yang mengalami luapan kala ulang 5 tahun dapat dilihat pada Tabel 6 sebagai berikut.

Tabel 6: Hasil Simulasi Debit Genangan per Saluran Kondisi Eksisting

\begin{tabular}{ccccccccc}
\hline No & $\begin{array}{c}\text { Nama } \\
\text { Saluran }\end{array}$ & $\begin{array}{c}\text { Lebar } \\
\text { Saluran } \\
(\mathrm{m})\end{array}$ & $\begin{array}{c}\text { Tinggi } \\
\text { Saluran } \\
(\mathrm{m})\end{array}$ & $\begin{array}{c}\text { Diameter } \\
(\mathrm{m})\end{array}$ & $\begin{array}{c}\text { Tinggi Air } \\
\text { Maksimum di } \\
\text { Saluran }(\mathrm{m})\end{array}$ & $\begin{array}{c}\text { Kecepatan } \\
\text { Maksimum } \\
(\mathrm{m} / \mathrm{dtk})\end{array}$ & $\begin{array}{c}\text { Debit } \\
\text { Maksimum } \\
\left(\mathrm{m}^{3} / \mathrm{dtk}\right)\end{array}$ & Ket. \\
\hline 1 & C2 & - & - & 0,16 & 0,16 & 0,76 & 0,015 & Meluap \\
2 & C9 & - & - & 0,1 & 0,10 & 0,33 & 0,002 & Meluap \\
3 & C19 & 0,3 & 0,15 & - & 0,15 & 1,22 & 0,054 & Meluap \\
4 & C33 & - & - & 0,16 & 0,16 & 0,62 & 0,012 & Meluap \\
5 & C38 & 0,2 & 0,3 & - & 0,30 & 0,81 & 0,046 & Meluap \\
6 & C39 & 0,3 & 0,2 & - & 0,20 & 1,60 & 0,093 & Meluap \\
7 & C40 & 0,25 & 0,2 & - & 0,20 & 0,71 & 0,035 & Meluap \\
8 & C42 & - & - & 0,16 & 0,16 & 0,55 & 0,010 & Meluap \\
\hline
\end{tabular}

Pada Tabel 5 dan Tabel 6 di atas merupakan hasil simulasi model SWMM pada jaringan drainase eksisting dengan intensitas hujan kala ulang 2 dan 5 tahun, didapatkan 8 dari jumlah total saluran pada kondisi di lapangan yaitu 42 saluran/conduit eksisting sudah tidak 
dapat menampung air limpasan/genangan yang terjadi. Dari hasil simulasi SWMM, air dalam saluran akan meluber jika tinggi air maksimum di saluran dalam saluran eksisting sama dengan tinggi dari saluran eksisting [10]. Lokasi genangan tersebut akan menjadi dasar penanggulangan genangan berbasis konservasi berupa penempatan untuk perencanaan sumur injeksi[10]. Dengan demikian maka, genangan permukaan air hujan pada sub DTA-sub DTA dapat ditampung sementara dan atau diresapkan terlebih dahulu sebelum masuk ke dalam saluran drainase[10]. Untuk contoh profil muka air pada beberapa titik lokasi genangan untuk kala ulang 2 dan 5 tahun hasil simulasi SWMM 5.1 juga dapat dilihat pada gambar sebagai berikut.

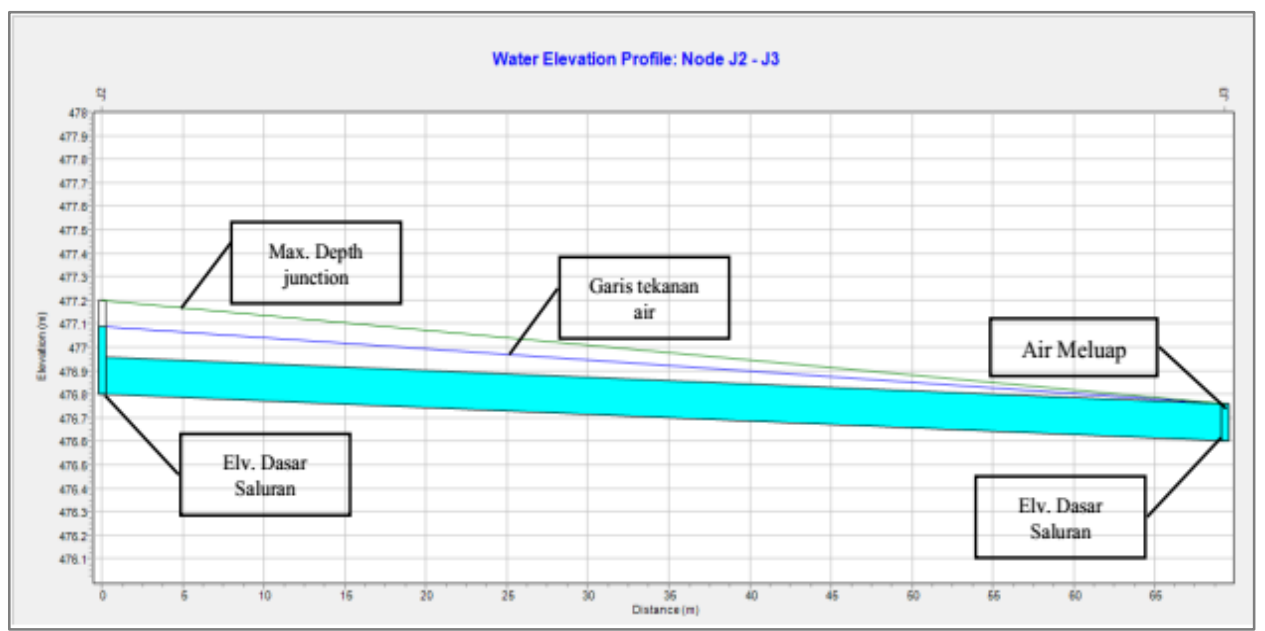

Gambar 3: Profil Muka Air Hasil Simulasi pada Kondisi Eksisting untuk Conduit 2 pada Jam 02:00 （Titik J2-J3)

Pada gambar 3 dapat dilihat untuk saluran C2 (titik J2-J3) bahwa tinggi air maksimum berada pada J3, sehingga dapat dikatakan bahwa saluran $\mathrm{C} 2$ mengalami luapan yang yang dapat dilihat air memenuhi kedalaman persimpangan maupun saluran pada titik J3.

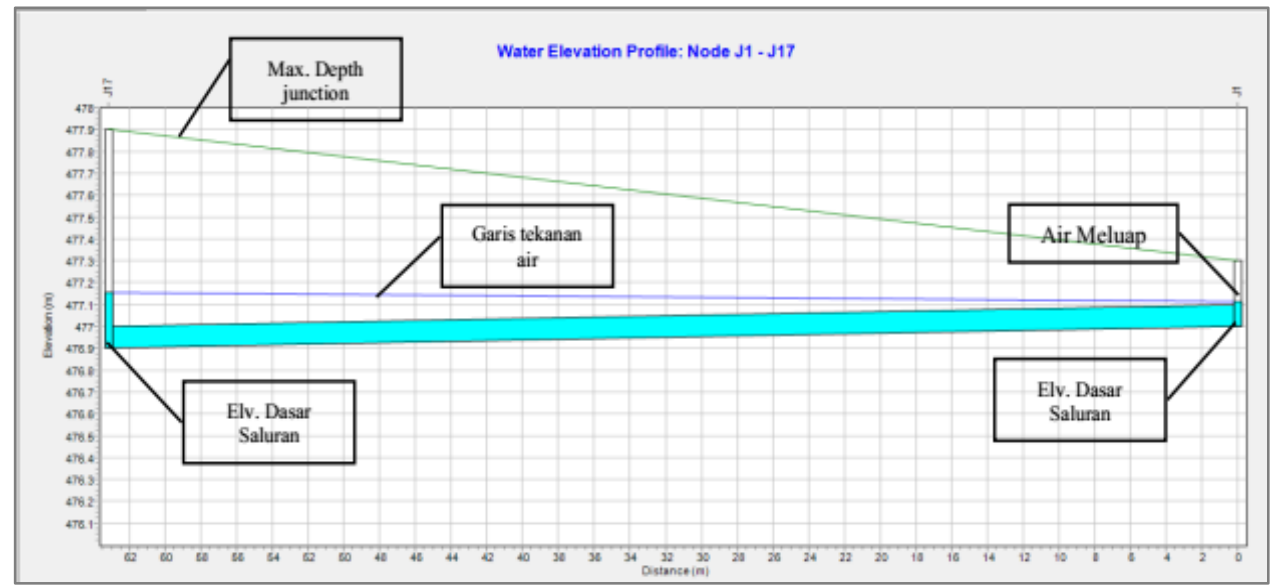

Gambar 4: Profil Muka Air Hasil Simulasi pada Kondisi Eksisting untuk Conduit pada Jam 02:00 (Titik J1-J17)

Pada gambar 4 dapat dilihat untuk saluran C9 (titik J1-J17) bahwa tinggi air maksimum berada pada J1, sehingga dapat dikatakan bahwa pada saluran C9 mengalami luapan yang dapat dilihat air memenuhi kedalaman persimpangan maupun saluran pada titik J1 . 


\subsection{Perencanaan Sumur Injeksi}

Sumur injeksi yang direncanakan pada lokasi studi penelitian akan diterapkan pada daerah genangan yang ada RW.8 dan 9, Kelurahan Blimbing. Penempatan dari sumur injeksi sesuai dengan lokasi daerah genangan yang didapatkan dari hasil pemodelan pada perangkat lunak Storm Water Management Model (SWMM 5.1).

Setelah dilakukan simulasi dengan kala ulang 2 tahun dan 5 tahun didapatkan dari total 42 saluran drainase, terdapat 8 saluran yang meluap. Lokasi sumur injeksi akan ditempatkan pada beberapa daerah yang menangkap genangan terdiri dari 8 daerah tangkapan air/hujan yaitu S3, S4, S5, S6, S10, S13, S14, dan S16. Dimensi dari sumur injeksi untuk masukan pada model aplikasi SWMM 5.1 yaitu untuk diameter sebesar 0,8 $\mathrm{m}$ dan kedalaman sebesar $5 \mathrm{~m}$. Penggambaran model dari sumur injeksi yang digunakan dapat dilihat pada Gambar 5.

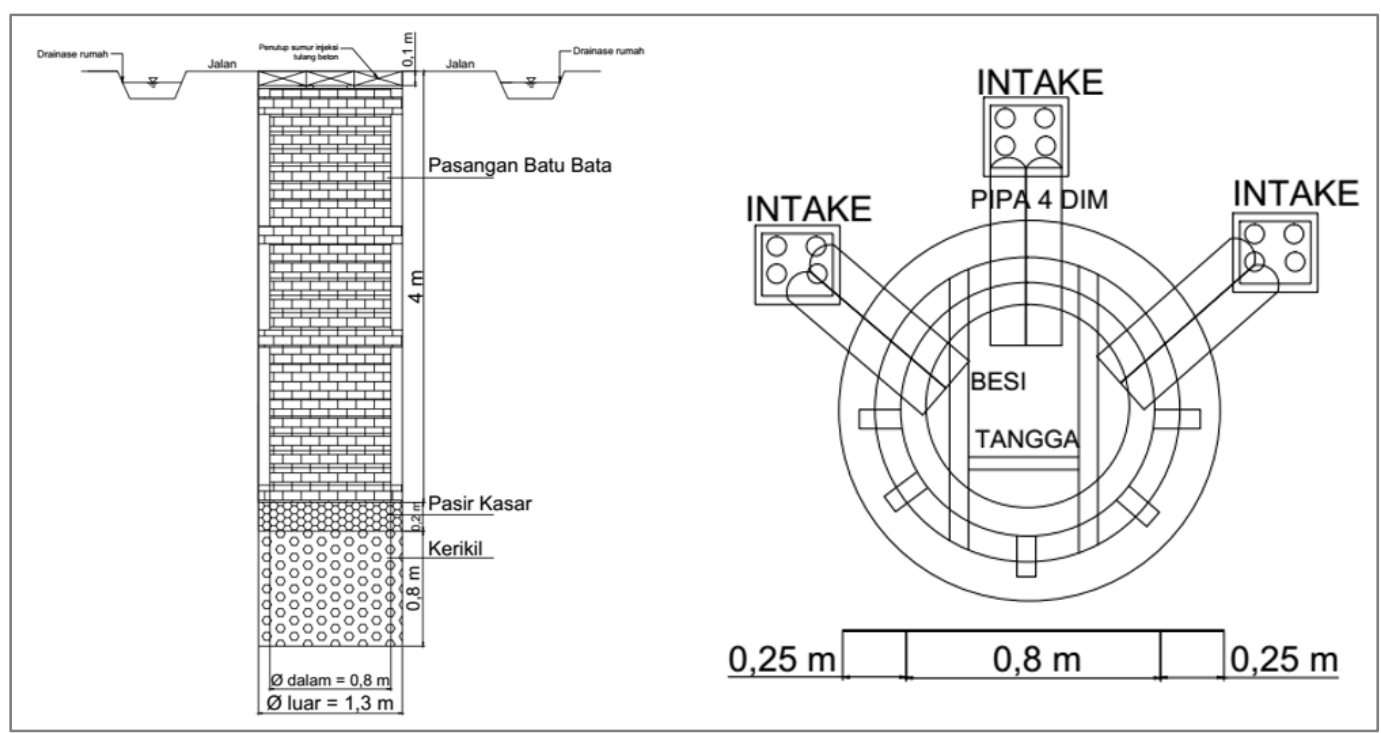

Gambar 5: Tampak Samping (kiri) dan Tampak Atas (kanan) Sumur Injeksi Tanpa Skala

\subsubsection{Kala Ulang 2 Tahun}

Rekapitulasi hasil penerapan simulasi sumur injeksi dengan menggunakan aplikasi SWMM 5.1 untuk kala ulang 2 tahun pada Tabel 7 berikut.

Tabel 7: Rekapitulasi Hasil Penerapan Simulasi Sumur Injeksi pada Saluran

\begin{tabular}{ccccccc}
\hline No & $\begin{array}{c}\text { Nama } \\
\text { Saluran }\end{array}$ & $\begin{array}{c}\text { Lebar } \\
\text { Saluran }(\mathrm{m})\end{array}$ & $\begin{array}{c}\text { Tinggi Saluran } \\
(\mathrm{m})\end{array}$ & $\mathrm{d}(\mathrm{m})$ & $\begin{array}{c}\text { Tinggi Air Maksimum } \\
\text { di Saluran }(\mathrm{m})\end{array}$ & Ket. \\
\hline 1 & C2 & - & - & 0,16 & 0,09 & Cukup \\
2 & C9 & - & - & 0,1 & 0,09 & Cukup \\
3 & C19 & 0,3 & 0,15 & - & 0,11 & Cukup \\
4 & C33 & 0,16 & 0,16 & - & 0,11 & Cukup \\
5 & C38 & 0,2 & 0,3 & - & 0,22 & Cukup \\
6 & C39 & 0,3 & 0,2 & - & 0,17 & Cukup \\
7 & C40 & 0,25 & 0,2 & - & 0,12 & Cukup \\
8 & C42 & - & - & 0,16 & 0,11 & Cukup \\
\hline
\end{tabular}

Data pada kondisi eksisting saluran drainase untuk kala ulang 2 tahun menunjukkan bahwa terdapat 8 titik yang meluap. Kemudian penanganan genangan dengan menerapkan 
sumur injeksi dan terbukti mampu mengubah 8 titik luapan tidak mengalami luapan pada salurannya. Contoh profil air setiap saluran setelah adanya penerapan sumur injeksi dapat dilihat pada gambar di bawah ini sebagai berikut.

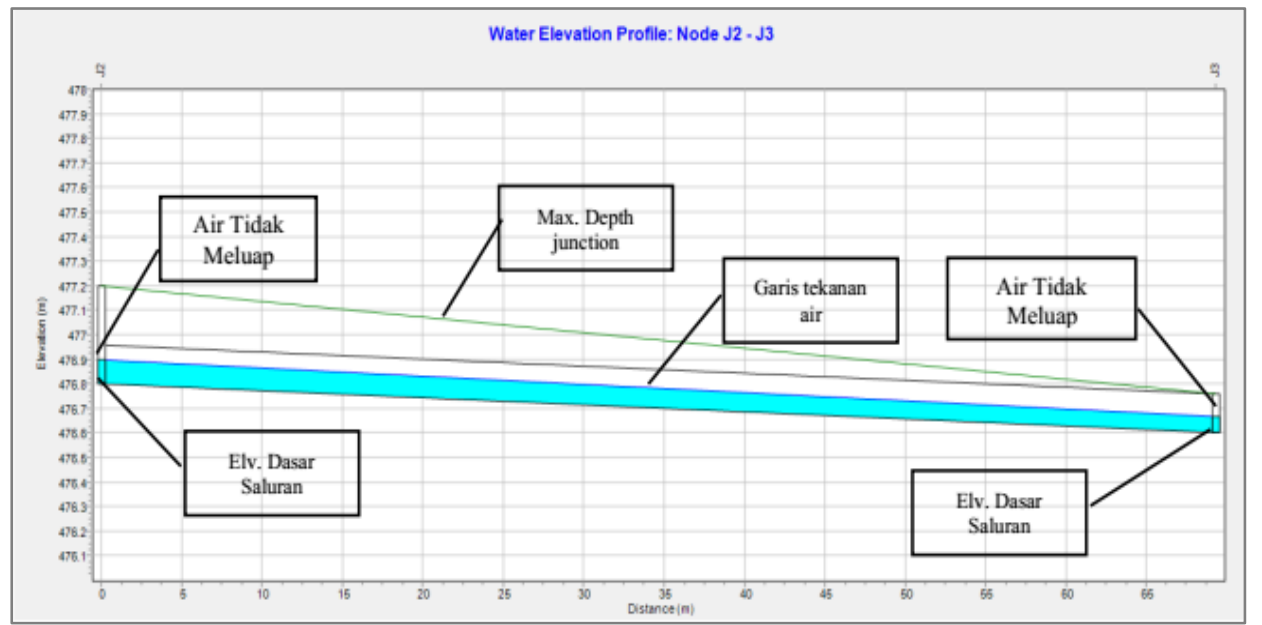

Gambar 6: Profil Air pada Saluran C2 Setelah Adanya Penerapan Sumur Injeksi pada Waktu 02:00 (Titik J2-J3)

Pada gambar 6 dapat dilihat untuk saluran C2 (titik J2-J3) setelah adanya penerapan sumur injeksi pada saluran C2 tidak mengalami luapan yang dilihat dari garis biru (garis tekanan air) dan garis hijau (kedalaman maksimum persimpangan) pada titik J2 dan J3 tidak melampaui garis elevasi yang ada.

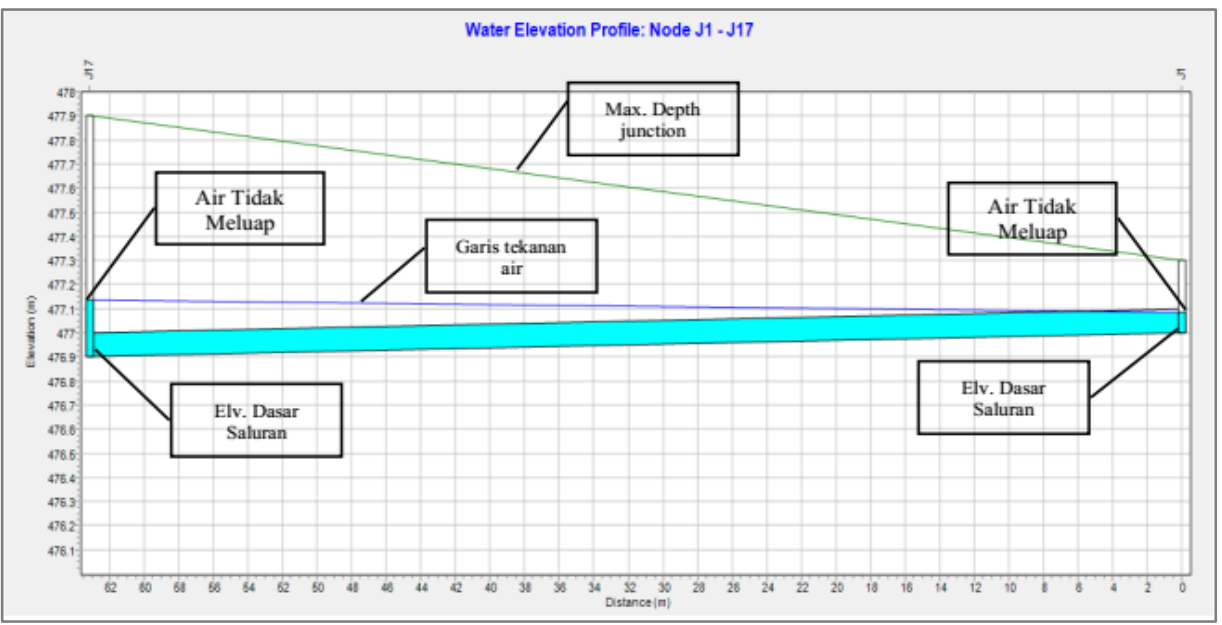

Gambar 7: Profil Air pada Saluran C9 Setelah Adanya Penerapan Sumur Injeksi pada Waktu 02:00 (Titik J1-J17)

Pada gambar 7 dapat dilihat untuk saluran C9 (titik J1-J17) setelah adanya penerapan sumur injeksi pada saluran C9 tidak mengalami luapan yang dilihat dari garis biru (garis tekanan air) dan garis hijau (kedalaman maksimum persimpangan) pada titik J1 dan J17 tidak melampaui garis elevasi yang ada.

\subsubsection{Kala Ulang 5 Tahun}

Rekapitulasi hasil penerapan simulasi sumur injeksi dengan menggunakan aplikasi SWMM 5.1 untuk kala ulang 5 tahun pada Tabel 8 berikut. 
Tabel 8: Rekapitulasi Hasil Penerapan Simulasi Sumur Injeksi pada Saluran

\begin{tabular}{ccccccc}
\hline No & $\begin{array}{c}\text { Nama } \\
\text { Saluran }\end{array}$ & $\begin{array}{c}\text { Lebar Saluran } \\
(\mathrm{m})\end{array}$ & $\begin{array}{c}\text { Tinggi Saluran } \\
(\mathrm{m})\end{array}$ & $\mathrm{d}(\mathrm{m})$ & $\begin{array}{c}\text { Tinggi Air Maksimum di } \\
\text { Saluran }(\mathrm{m})\end{array}$ & Ket. \\
\hline 1 & C2 & - & - & 0,16 & 0,09 & Cukup \\
2 & C9 & - & - & 0,1 & 0,09 & Cukup \\
3 & C19 & 0,3 & 0,15 & - & 0,11 & Cukup \\
4 & C33 & 0,16 & 0,16 & - & 0,12 & Cukup \\
5 & C38 & 0,2 & 0,3 & - & 0,23 & Cukup \\
6 & C39 & 0,3 & 0,2 & - & 0,18 & Cukup \\
7 & C40 & 0,25 & 0,2 & - & 0,14 & Cukup \\
8 & C42 & - & - & 0,16 & 0,12 & Cukup \\
\hline
\end{tabular}

Data pada kondisi eksisting saluran drainase untuk kala ulang 5 tahun menunjukkan bahwa terdapat 8 titik yang meluap. Kemudian dilakukan penanganan genangan dengan menerapkan sumur injeksi dan terbukti mampu mengubah 8 titik luapan tidak mengalami luapan pada salurannya. Contoh profil air setiap saluran setelah adanya penerapan sumur injeksi dapat dilihat pada gambar di bawah ini sebagai berikut.

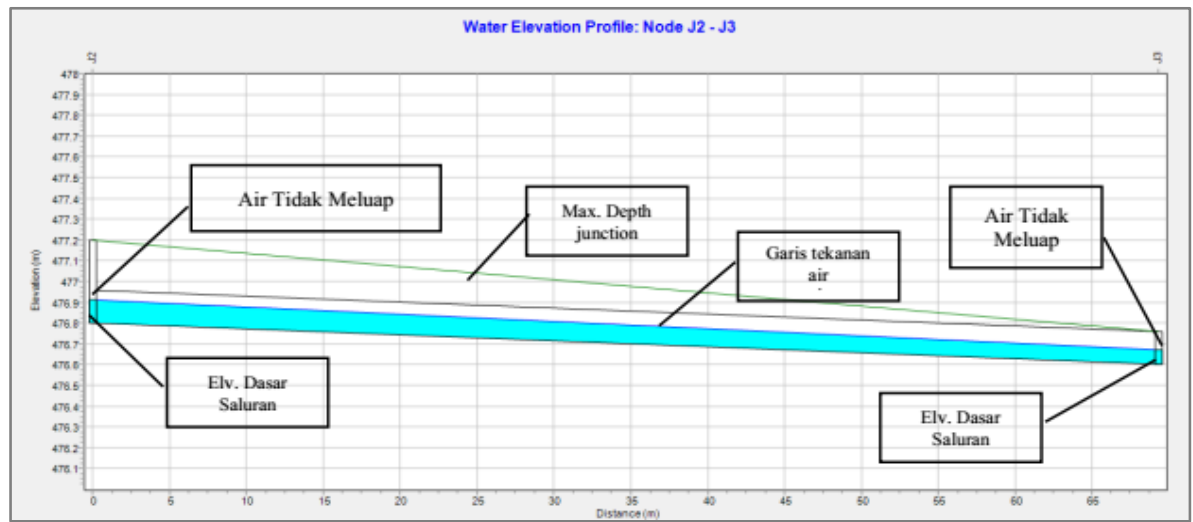

Gambar 8: Profil Air pada Saluran C2 Setelah Adanya Penerapan Sumur Injeksi pada Waktu 02:00 (Titik J2-J3)

Pada gambar 8 dapat dilihat untuk saluran C2 (titik J2-J3) setelah adanya penerapan sumur injeksi pada saluran C2 tidak mengalami luapan yang dilihat dari garis biru (garis tekanan air) dan garis hijau (kedalaman maksimum persimpangan) pada titik J2 dan J3 tidak melampaui garis elevasi yang ada.

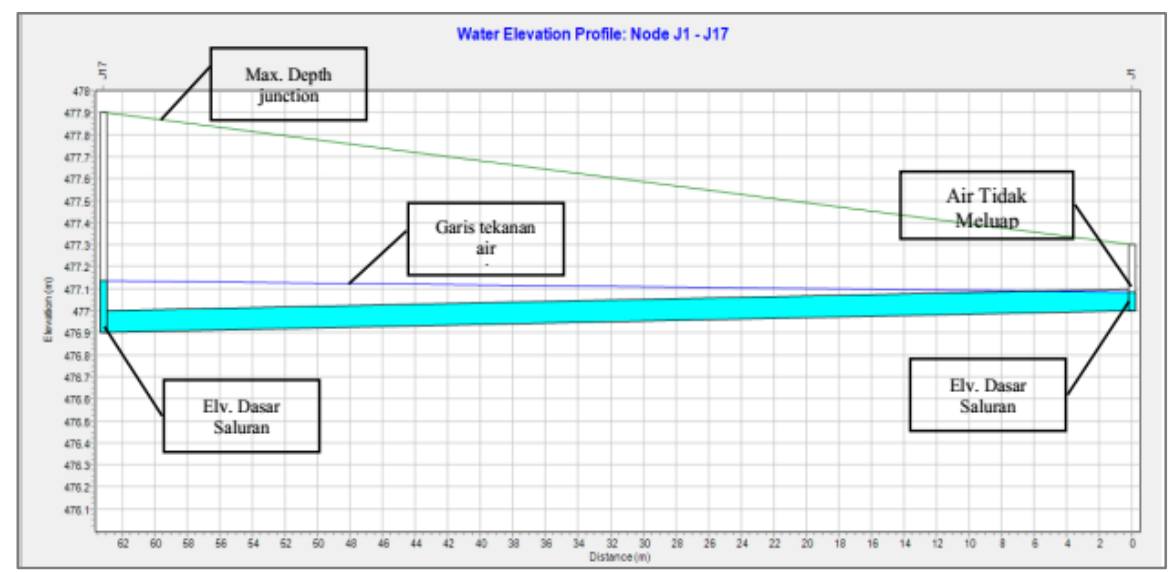

Gambar 9: Profil Air pada Saluran C9 Setelah Adanya Penerapan Sumur Injeksi pada Waktu 02:00 (Titik J1-J17) 
Pada gambar 9 dapat dilihat untuk saluran C9 (titik J1-J17) setelah adanya penerapan sumur injeksi pada saluran C9 tidak mengalami luapan yang dilihat dari garis biru (garis tekanan air) dan garis hijau (kedalaman maksimum persimpangan) pada titik J1 dan J17 tidak melampaui garis elevasi yang ada.

\subsubsection{Peta Penempatan Sumur Injeksi}

Berikut di bawah ini adalah hasil peta penempatan sumur injeksi beserta contoh layout sumur injeksi pada setiap daerah tangkapan air, sumur injeksi yang dibutuhkan sesuai dengan masukan pada aplikasi SWMM 5.1. Untuk contoh dari peta lokasi penempatan sumur injeksi untuk kala ulang 2 tahun dan 5 tahun dapat dilihat di bawah ini sebagai berikut.

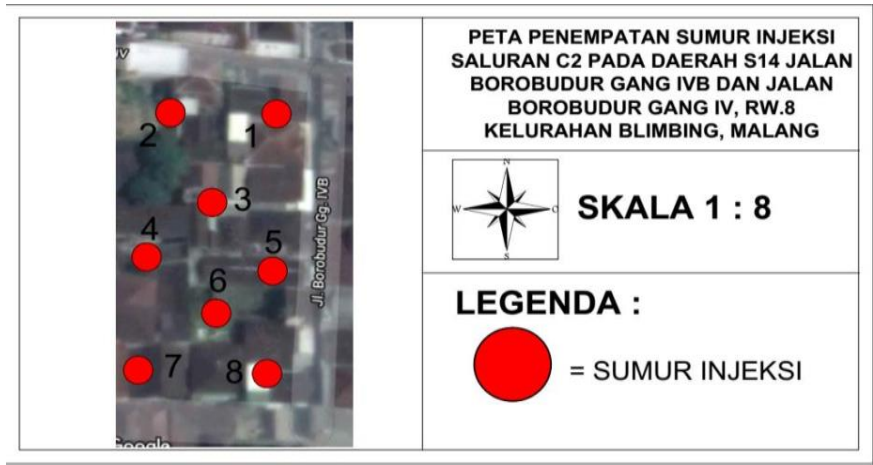

Gambar 10: Peta Penempatan Sumur Injeksi Saluran C2 pada Daerah S14

Pada gambar 10, peta penempatan sumur injeksi pada saluran $\mathrm{C} 2$ yang tergenang pada daerah S14 RW.8 Kelurahan Blimbing, Kecamatan Blimbing terdapat 8 titik sumur injeksi ditempatkan di daerah tersebut.

\subsection{Efektivitas Penerapan Sumur Injeksi}

Tabel 9: Nilai Reduksi Genangan dan Efektivitas Sumur Injeksi untuk Hasil Simulasi Kala Ulang 2 Tahun dan 5 Tahun

\begin{tabular}{|c|c|c|c|c|c|c|c|c|}
\hline \multirow[b]{2}{*}{ No. } & \multirow[b]{2}{*}{ Saluran } & \multirow[b]{2}{*}{$\begin{array}{l}\text { Sub } \\
\text { DTA }\end{array}$} & \multicolumn{3}{|c|}{ Kala Ulang 2 Tahun } & \multicolumn{3}{|c|}{ Kala Ulang 5 Tahun } \\
\hline & & & $\begin{array}{c}\text { Volume } \\
\text { Genangan } \\
\text { Awal }\left(\mathrm{m}^{3}\right)\end{array}$ & $\begin{array}{c}\text { Volume } \\
\text { Genangan } \\
\text { Adanya } \\
\text { Sumur } \\
\left(\mathrm{m}^{3}\right)\end{array}$ & $\begin{array}{l}\text { Efektivitas } \\
\text { Sumur }(\%)\end{array}$ & $\begin{array}{c}\text { Volume } \\
\text { Genangan } \\
\text { Awal }\left(\mathrm{m}^{3}\right)\end{array}$ & $\begin{array}{l}\text { Volume } \\
\text { Genangan } \\
\text { Adanya } \\
\text { Sumur } \\
\left(\mathrm{m}^{3}\right)\end{array}$ & $\begin{array}{l}\text { Efektivitas } \\
\text { Sumur (\%) }\end{array}$ \\
\hline 1. & $\mathrm{C} 2$ & S14 & 150 & 10 & 93,33 & 190 & 10 & 94,74 \\
\hline 2. & C9 & S3 & 220 & 40 & 81,82 & 280 & 60 & 78,57 \\
\hline 3. & C19 & S5 & 390 & 130 & 66,67 & 500 & 170 & 66,00 \\
\hline 4. & C33 & S10 & 340 & 80 & 76,47 & 430 & 100 & 76,74 \\
\hline 5. & $\mathrm{C} 38$ & S16 & 190 & 30 & 84,21 & 240 & 40 & 83,33 \\
\hline 6. & C39 & $\mathrm{S} 4$ & 290 & 20 & 93,10 & 380 & 20 & 94,74 \\
\hline 7. & $\mathrm{C} 40$ & S6 & 430 & 50 & 88,37 & 550 & 60 & 89,09 \\
\hline 8. & $\mathrm{C} 42$ & S13 & 150 & 10 & 93,33 & 200 & 10 & 95,00 \\
\hline & Ef & ivitas & ata-Rata $(\%$ & & 84,66 & & & 84,78 \\
\hline
\end{tabular}


Dapat dicontohkan untuk perhitungan pada Tabel 9 pada saluran C40 yang mana berada pada daerah tangkapan air S6 untuk kala ulang 2 tahun didapatkan nilai volume genangan sebelum ada sumur injeksi sebesar $0,43 \times 10^{6}$ liter dan volume genangan setelah adanya sumur injeksi sebesar $0,05 \times 10^{6}$ liter. Nilai tersebut dikonversikan $\mathrm{ke}^{3}$ (meter kubik) didapatkan nilai volume genangan sebelum ada sumur injeksi adalah $430 \mathrm{~m}^{3}$ dan volume genangan setelah ada sumur injeksi didapatkan $50 \mathrm{~m}^{3}$. Sehingga efektivitas penerapan sumur injeksi dapat dihitung dengan rumus sebagai berikut:

$$
\begin{aligned}
\text { Efektivitas }(\%) & =\frac{\text { Vol.genangan }- \text { Vol.genangan setelah ada sumur injeksi }}{\text { Volume genangan }} \times 100 \% \\
& =\frac{430-50}{430} \times 100 \% \\
& =\frac{380}{430} \times 100 \% \\
& =\mathbf{8 8 , 3 7 \%}
\end{aligned}
$$

Dari hasil di atas pada Tabel 9 maka didapatkan efektivitas rata-rata sumur injeksi untuk kala ulang 2 tahun sebesar 84,66\% dan untuk kala ulang 5 tahun sebesar 84,78\%, dalam hal ini nilai efektivitas sumur injeksi untuk kala ulang 5 tahun lebih besar jika dibandingkan dengan kala ulang 2 tahun.

\section{Kesimpulan}

Dari hasil survei dan penyelidikan di lapangan kemudian diolah datanya menggunakan aplikasi SWMM 5.1 didapatkan hasil bahwa kapasitas saluran drainase eksisting di RW.8 dan 9, Kelurahan Blimbing kala ulang hujan 2 tahun dan 5 tahun dihasilkan bahwa terdapat 8 titik saluran drainase yang mengalami genangan.

Perencanaan sumur injeksi menggunakan desain sumur injeksi Nomor Paten IDP000040509 kemudian dimasukkan ke aplikasi SWMM 5.1 didapatkan bahwa dibutuhkan sebanyak 45 sumur injeksi dengan diameter sebesar $0,8 \mathrm{~m}$ dan kedalaman sebesar $5 \mathrm{~m}$ pada 8 lokasi daerah tangkapan air.

Nilai efektivitas sumur injeksi pada kala ulang 2 tahun didapatkan sebesar 66,67\% 93,33\% dengan rata-rata sebesar 84,66\%, dengan saluran C19 memiliki nilai efektivitas terendah sebesar $66,67 \%$ dan saluran $\mathrm{C} 2$ dan C42 memiliki nilai efektivitas tertinggi sebesar 93,33\%. Sedangkan hasil untuk nilai efektivitas sumur injeksi pada kala ulang 5 tahun sebesar 66\% - 95\% dengan rata-rata sebesar 84,78\%, dengan saluran C19 memiliki nilai efektivitas terendah sebesar $66 \%$ dan saluran $\mathrm{C} 42$ memiliki nilai efektivitas tertinggi sebesar $95 \%$.

\section{Daftar Pustaka}

[1] Bahunta, L., \& Waspodo, B. R, "Rancangan Sumur Resapan Air Hujan Sebagai Upaya Pengurangan Limpasan Di Kampung Babakan, Cibinong, Kabupaten Bogor,” Jurnal Teknik Sipil Dan Lingkungan, vol. 04, no. 01, pp. 37-48, 2019. 
[2] Rossman L., \& Huber W.C, Storm Water Management Model Reference Manual Volume I-Hydrology (Revised), Cincinnati (US): EPA United States Environmental Agency, 2016.

[3] Widyanarko, E, "Kajian Evaluasi Sistem Drainase (Jalan Cenderawasih Kecamatan Patrang Kabupaten Jember)," Skripsi, Fakultas Teknik, Jurusan Teknik Sipil, Universitas Jember, Jember, 2015.

[4] Husain, M, "Studi Evaluasi Sistem Saluran Drainase di Jalan Soekarno Hatta," Skripsi, Fakultas Teknologi Pertanian, Jurusan Teknik Lingkungan, Universitas Brawijaya, Malang, 2017.

[5] Ajitama, A.S, “Analisa Reduksi Debit Saluran Dengan Penerapan Rain Water Harvesting Menggunakan Aplikasi EPA SWMM 5.1 Di Perumahan Sukolilo Dian Regency Kota Surabaya," Skripsi, Fakultas Teknik, Jurusan Teknik Pengairan, Universitas Brawijaya, Malang, 2017.

[6] Soewarno, "Hidrologi Aplikasi Metode Statistik Untuk Analisa Data", Nova : Bandung, 1995.

[7] Badan Standarisasi Nasional, "SNI 03-2415-1991 Rev. 2004 : Tata Cara Perhitungan Debit Banjir," 2004.

[8] Ardiyana, M, "Studi Penerapan Ecodrain Pada Sistem Drainase Perkotaan (Studi Kasus : Perumahan Sawojajar Kota Malang),” vol. 7, no. 2, pp. 295-309, 2016.

[9] Faskal. "Alternatif Pengendalian Banjir untuk Sungai Linei, Kota Toboali (Studi kasus wilayah Rawabangun)," Tesis, Fakultas Teknik, Jurusan Teknik Pengairan, Universitas Brawijaya, Malang, 2019.

[10] Sebandar, Mauluddin, "Studi Alternatif Penanggulangan Genangan Berbasis Konservasi Di Sistem Drainase Oesapa-Lasiana Kota Kupang,” vol. 9, no. 2, pp. 125-137, 2018. 